ARTICLE

Received 21 Oct 2013 | Accepted 10 Mar 2014 | Published 7 April $2014 \quad$ DOl: 10.1038/ncomms4601

\title{
Smart responsive phosphorescent materials for data recording and security protection
}

Huibin Sun ${ }^{1,2, *}$, Shujuan Liu, ${ }^{1, *}$, Wenpeng Lin' ${ }^{1}$ Kenneth Yin Zhang ${ }^{1}$, Wen Lv' ${ }^{1}$ Xiao Huang ${ }^{2}$, Fengwei Huo ${ }^{2}$, Huiran Yang ${ }^{1}$, Gareth Jenkins ${ }^{1,2}$, Qiang Zhao $^{1} \&$ Wei Huang ${ }^{1,2}$

Smart luminescent materials that are responsive to external stimuli have received considerable interest. Here we report ionic iridium (III) complexes simultaneously exhibiting mechanochromic, vapochromic and electrochromic phosphorescence. These complexes share the same phosphorescent iridium (III) cation with a N-H moiety in the $\mathrm{N} \wedge^{\wedge} \mathrm{N}$ ligand and contain different anions, including hexafluorophosphate, tetrafluoroborate, iodide, bromide and chloride. The anionic counterions cause a variation in the emission colours of the complexes from yellow to green by forming hydrogen bonds with the $\mathrm{N}-\mathrm{H}$ proton. The electronic effect of the $\mathrm{N}-\mathrm{H}$ moiety is sensitive towards mechanical grinding, solvent vapour and electric field, resulting in mechanochromic, vapochromic and electrochromic phosphorescence. On the basis of these findings, we construct a data-recording device and demonstrate data encryption and decryption via fluorescence lifetime imaging and time-gated luminescence imaging techniques. Our results suggest that rationally designed phosphorescent complexes may be promising candidates for advanced data recording and security protection.

\footnotetext{
${ }^{1}$ Key Laboratory for Organic Electronics \& Information Displays and Institute of Advanced Materials, Nanjing University of Posts \& Telecommunications, 9 Wenyuan Road, Nanjing 210023, China. ${ }^{2}$ Institute of Advanced Materials and Jiangsu-Singapore Joint Research Center for Organic/Bio- Electronics \& Information Displays, Nanjing Tech University, 30 South Puzhu Road, Nanjing 211816, China. * These authors contributed equally to this work. Correspondence and requests for materials should be addressed to Q.Z. (email: iamqzhao@njupt.edu.cn) or to W.H. (email: wei-huang@njtech.edu.cn).
} 
$\mathrm{D}$ ata recording, storage and security technologies have been widely utilized in economic and military fields as well as in our daily life. Smart luminescent materials that are responsive to external stimuli have received considerable attention in the construction of optical data recording and storage devices ${ }^{1-5}$. These materials have been classified on the basis of the types of external stimuli that they are responsive to. Mechanochromic materials show changes in emission colour in the presence of mechanical stimuli (for example, shearing, grinding and rubbing) because of the interruption of intermolecular interactions (for example, $\pi-\pi$ stacking and hydrogen bonds $)^{6-10}$. Vapochromic luminescence has been observed in materials that are responsive to volatile organic compounds ${ }^{11,12}$. Electric field is an important external stimulus. Electrochromism occurs in $\pi$-conjugated polymers because of the reversible transition between two redox states ${ }^{13-16}$. However, materials showing electrochromic luminescence, which is distinct luminescence colour responses to an electric field, are scarce. We envision the potential commercial applications of electrochromic luminescent materials because they can be conveniently integrated into semiconductor-based electronic devices. In addition, it is conceivable that compounds simultaneously showing mechanochromic, vapochromic and electrochromic luminescence are of great use to the development of multifunctional materials.

Phosphorescent transition-metal complexes, such as those of Ir(III) and Pt(II), have been extensively studied for various photonic and electronic applications because of their rich excited-state properties, including high luminescence quantum yields, long emission lifetimes, large Stokes shifts, high photostability and various luminescence colours ${ }^{17-20}$. These complexes have also been utilized as external stimuli-responsive materials because of their highly sensitive photophysical properties to the microenvironment ${ }^{21-23}$. In addition, the long-lived phosphorescence of these complexes renders them suitable for a time-resolved luminescence technique, which is incompatible with short-lived fluorescent dyes ${ }^{24,25}$. In view of these interesting phosphorescence properties, in particular their high sensitivity to external stimuli and long phosphorescence lifetime, we believe that transition-metal complexes have a great potential to serve as materials for optical data recording and security protection.

In this study, we report a series of ionic $\operatorname{Ir}(\mathrm{III})$ complexes sharing the same phosphorescent $\mathrm{Ir}(\mathrm{III})$ cation with a $\mathrm{N}-\mathrm{H}$ moiety in the $\mathrm{N}^{\wedge} \mathrm{N}$ ligand and containing different counterions including $\mathrm{PF}_{6}^{-}, \mathrm{BF}_{4}^{-}, \mathrm{I}^{-}, \mathrm{Br}^{-}$and $\mathrm{Cl}^{-}$. The anionic counterions cause a variation in the emission colours of the complexes by forming hydrogen bonds with the $\mathrm{N}-\mathrm{H}$ proton. Interestingly, the emission colours of these complexes are sensitive to mechanical, volatile organic compounds and electrical stimuli, all of which influence the electronic effect of the $\mathrm{N}-\mathrm{H}$ moiety in the $\mathrm{N}^{\wedge} \mathrm{N}$ ligand. On the basis of our findings, a quasi-solid data recording and storage device is fabricated to show the evident luminescence colour change from yellow to green at a low voltage. Owing to the advantageous long phosphorescence lifetime of the $\operatorname{Ir}(\mathrm{III})$ complexes, data encryption and decryption are demonstrated via the fluorescence lifetime imaging microscopy (FLIM) and time-gated luminescence imaging (TGLI) techniques.

\section{Results}

Synthesis and characterization of the $\operatorname{Ir}(\mathrm{III})$ complexes. This study presents a universal approach that uses mechanochromic, vapochromic and electrochromic phosphorescence of $\operatorname{Ir}(\mathrm{III})$ complexes for data recording and security protection. Our designed complexes $\left[\mathrm{ppy}_{2} \mathrm{IrNH}\right]{ }^{+} \mathrm{A}^{-}$(ppy $=2$-phenylpyridine, $\mathrm{A}^{-}=\mathrm{PF}_{6}^{-}$(1), $\mathrm{BF}_{4}^{-}$(2), $\mathrm{I}^{-}$(3), $\mathrm{Br}^{-}$(4) and $\mathrm{Cl}^{-}$(5), see
Fig. 1a) share the same phosphorescent $\operatorname{Ir}(\mathrm{III})$ cation with the $\mathrm{N}^{\wedge} \mathrm{N}$ ligand, 2-(2-pyridyl)benzimidazole $(\mathrm{NH})$, which contains a $\mathrm{N}-\mathrm{H}$ moiety, the electronic effect of which is sensitive to external stimuli. Different anionic counterions $\left(\mathrm{A}^{-}\right)$have been involved via anion exchange reactions. In addition, complexes $\left[\mathrm{pq}_{2} \mathrm{IrNH}\right]^{+} \mathrm{A}^{-} \quad\left(\mathrm{pq}=2\right.$-phenylquinoline, $\mathrm{A}^{-}=\mathrm{PF}_{6}^{-} \quad(\mathbf{6})$, $\mathrm{I}^{-}(7), \mathrm{Br}^{-}(8)$ and $\left.\mathrm{Cl}^{-}(\mathbf{9})\right)$ and $\left[\mathrm{ppy}_{2} \mathrm{IrNEt}{ }^{+} \mathrm{A}^{-}(\mathrm{Et}=\mathrm{ethyl}\right.$, $\mathrm{A}^{-}=\mathrm{PF}_{6}^{-}(\mathbf{1 0})$ and $\mathrm{Br}^{-}(\mathbf{1 1})$ ), in which ppy was replaced by a more conjugated pq ligand or the sensitivity of the $\mathrm{N}-\mathrm{H}$ moiety was eliminated by an ethyl substitution, have also been synthesized for comparison study (see Fig. 1b). The complexes were characterized via FTIR, ${ }^{1} \mathrm{H}$ NMR, ${ }^{3} \mathrm{C}$ NMR, ${ }^{19} \mathrm{~F}$ NMR, matrix-assisted laser desorption ionization time-of-flight mass spectrometry (MALDI-TOF MS), electrospray ionization mass spectrometry (ESI-MS), (see Supplementary Figs 1-11) X-ray crystal structure analysis (see Supplementary Data 1-4 and Supplementary Table 1), UV/Vis absorption spectrometry and steady-state fluorescence spectrometry.

The variation in the anionic counterions in $\left[\mathrm{ppy}_{2} \mathrm{IrNH}\right]^{+} \mathrm{A}^{-}$ was confirmed using their X-ray single-crystal structures (see Fig. 1c), ${ }^{1} \mathrm{H}$ NMR spectra (see Fig. 2a) and FTIR spectra (see Supplementary Fig. 12). Single crystals of $\left[\mathrm{ppy}_{2} \mathrm{IrNH}\right]^{+} \mathrm{PF}_{6}^{-}$, $\left[\mathrm{ppy}_{2} \mathrm{IrNH}\right]^{+} \mathrm{BF}_{4}^{-}$and $\left[\mathrm{ppy}_{2} \mathrm{IrNH}\right]^{+} \mathrm{Br}^{-}$that are suitable for $\mathrm{X}$-ray crystallography were obtained from addition of hexane to their $\mathrm{CH}_{2} \mathrm{Cl}_{2}$ solution. Supplementary Table 2 listed the selected bond lengths. Interestingly, multiple interactions such as hydrogen bonds and $\pi-\pi$ stacking were observed in the single crystals (see Supplementary Figs 13-16). For example, in [ppy $2 \mathrm{IrNH}]^{+} \mathrm{PF}_{6}^{-}$, the $\mathrm{N}-\mathrm{H}$ bond points towards one of the fluorine atoms of $\mathrm{PF}_{6}^{-}$with a N2 $\cdots \mathrm{F} 4$ distance of 3.08(1) $\AA$, which indicates the presence of the $\mathrm{N} 2-\mathrm{H}^{\cdots} \cdots \mathrm{F} 4$ hydrogen bond. In addition, $\pi-\pi$ stacking occurs between benzimidazole rings of adjacent molecules with an interplanar separation of $\sim 3.26 \AA$. In $\left[\mathrm{ppy}_{2} \mathrm{IrNH}\right]^{+} \mathrm{BF}_{4}^{-}$and $\left[\mathrm{ppy}_{2} \mathrm{IrNH}\right]^{+} \mathrm{Br}^{-}$, a N11 $\cdots \mathrm{F} 1$ distance of 2.824(9) $\AA$ and a N5 $\cdots$ Brl distance of 3.24(2) $\AA$ were observed, respectively, which indicates the hydrogen-bonding interactions. Moreover, the chemical shifts of the N-H proton in ${ }^{1} \mathrm{H}$ NMR spectra indicated the formation of hydrogen bonds with the counterions in solution. The signal of this proton displayed a marked downfield shift when counterion changed from $\mathrm{PF}_{6}^{-}$to $\mathrm{Cl}^{-}$, which is in agreement with the reported hydrogen bondaccepting capability of the anions in solutions $\left(\mathrm{PF}_{6}^{-}<\mathrm{BF}_{4}^{-}<\mathrm{I}^{-}\right.$ $\left.<\mathrm{Br}^{-}<\mathrm{Cl}^{-}\right)^{26,27}$. Previous reports have also confirmed this observation that revealed the formation or strengthening of hydrogen bonds leads to a decrease in the electron density on the bonding hydrogen atom and an increase on the acceptor and donor heteroatoms ${ }^{28-30}$, thereby resulting in a downfield shift of the proton chemical shift ${ }^{31}$.

Counterion-dependent phosphorescence. All the Ir(III) complexes exhibit intense and long-lived phosphorescence (see Supplementary Fig. 17) at room temperature upon photoexcitation. The photophysical data of the Ir(III) complexes have been summarized in Table 1, and the photoluminescence spectra of the complexes $(10 \mu \mathrm{M})$ in $\mathrm{CH}_{2} \mathrm{Cl}_{2}$ at room temperature have been shown in Fig. 2b. The luminescence quantum yield of $\left[\mathrm{ppy}_{2} \mathrm{IrNH}\right]^{+} \mathrm{I}^{-}$was reduced compared with those of the other complexes, and this result has been tentatively attributed to the most significant heavy atom effect of iodine among halogen ${ }^{32}$. The variation in anionic counterions caused a negligible effect on the absorption spectra of the complexes (see Supplementary Fig. 18), but, interestingly, the emission wavelengths of the complexes varied from 588 to $532 \mathrm{~nm}$. The counterion-induced emission colour change was probably caused by the $\mathrm{N}-\mathrm{H}{ }^{\cdots} \mathrm{X}$ ( $\mathrm{X}=$ halogen) hydrogen bond. As described in the ${ }^{1} \mathrm{H}$ NMR 
a

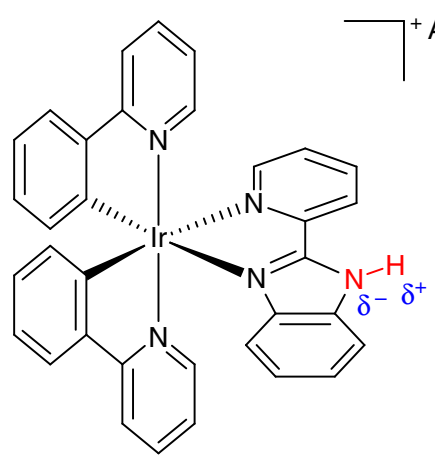

$\left[\mathrm{ppy}_{2} \mathrm{IrNH}\right]^{+} \mathrm{A}^{-}$

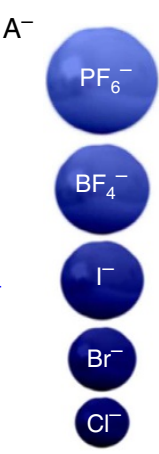

$\mathrm{A}^{-}$

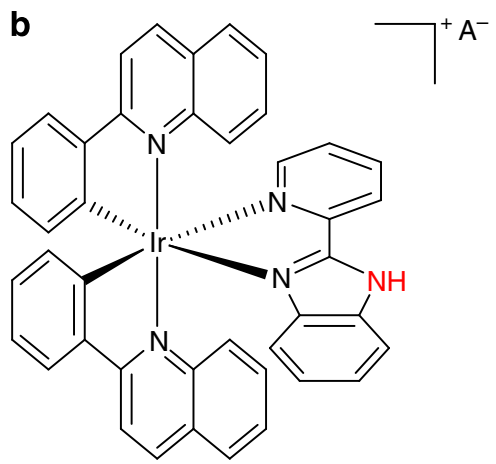

$\left[\mathrm{pq}_{2} \mathrm{IrNH}\right]^{+} \mathrm{A}^{-}$ $\mathrm{A}=\mathrm{PF}_{6}^{-}, \mathrm{I}^{-}, \mathrm{Br}^{-}$and $\mathrm{Cl}^{-}$

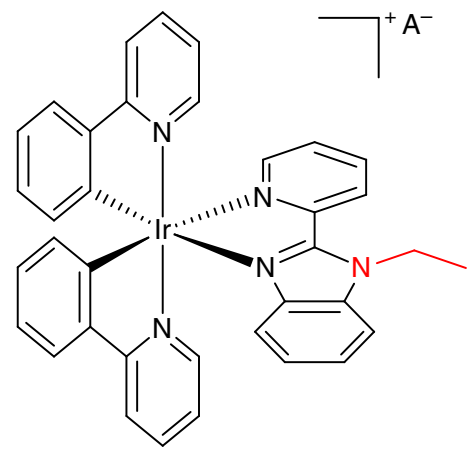

$\left[\text { ppy }_{2} \text { IrNEt }\right]^{+} \mathrm{A}^{-}$

$\mathrm{A}=\mathrm{PF}_{6}{ }^{-}$and $\mathrm{Br}^{-}$

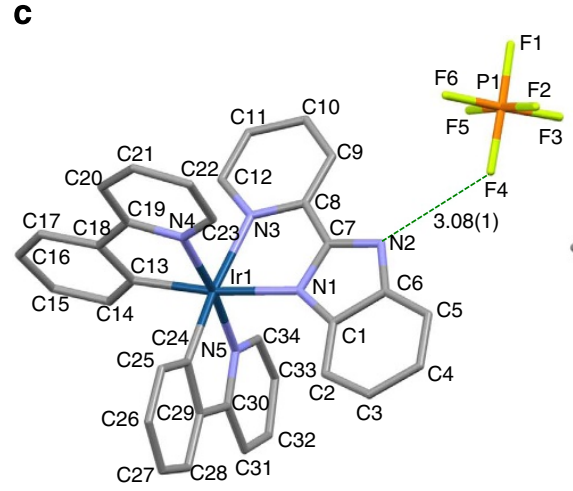

$\left[\mathrm{ppy}_{2} \mathrm{IrNH}\right]^{+} \mathrm{PF}_{6}{ }^{-}$

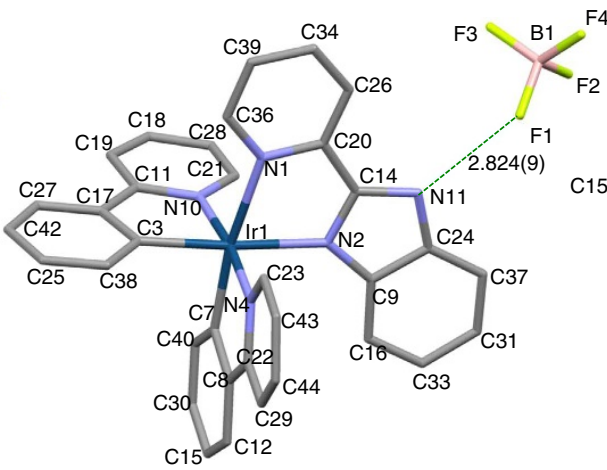

$\left[\mathrm{ppy}_{2} \mathrm{IrNH}\right]^{+} \mathrm{BF}_{4}^{-}$

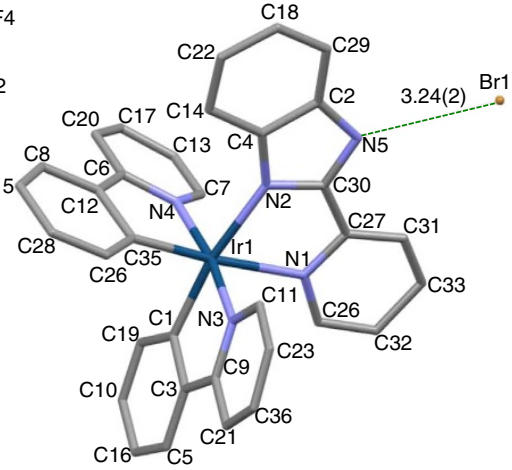

$\left[\mathrm{ppy}_{2} \mathrm{IrNH}\right]^{+} \mathrm{Br}^{-}$

Figure 1 | Molecular structures and crystal structures. (a) Chemical structures of $\left[\mathrm{ppy}_{2} \mathrm{IrNH}\right]^{+} \mathrm{A}^{-}$. (b) Chemical structures of $\left[\mathrm{pq}_{2} \mathrm{lrNH}\right]^{+} \mathrm{A}^{-}$and $\left[\mathrm{ppy}_{2} \mid \mathrm{rNEt}\right]^{+} \mathrm{A}^{-}$. (c) Single-crystal structures of complexes $\left[\mathrm{ppy}_{2} \mid \mathrm{rNH}\right]^{+} \mathrm{PF}_{6}^{-},\left[\mathrm{ppy}_{2} \mid \mathrm{rNH}\right]^{+} \mathrm{BF}_{4}^{-}$and $\left[\mathrm{ppy}_{2} \mid \mathrm{rNH}\right]^{+} \mathrm{Br}^{-}$, collected at $296 \mathrm{~K}$.
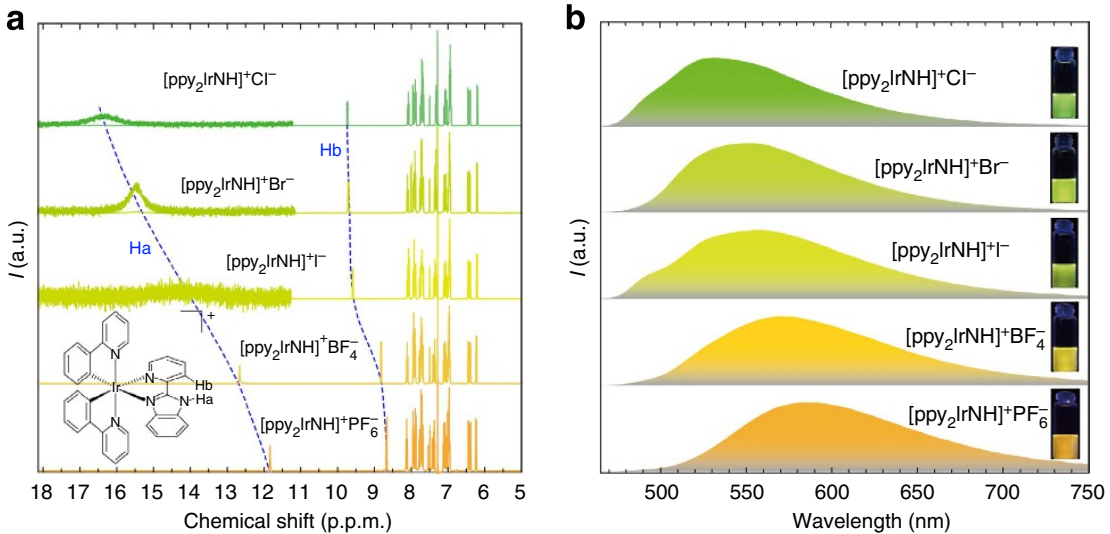

Figure 2 | ${ }^{\mathbf{H}}$ NMR characterization and optical features. (a) ${ }^{1} \mathrm{H}$ NMR spectra of $\left[\mathrm{ppy}_{2} \mathrm{IrNH}\right]^{+} \mathrm{A}^{-}$in $\mathrm{CDCl}_{3}$. (b) Photoluminescence spectra of [ppy $2 \mathrm{lrNH}]^{+} \mathrm{A}^{-}$in $\mathrm{CH}_{2} \mathrm{Cl}_{2}$ at $296 \mathrm{~K}\left(10 \mu \mathrm{M}, \lambda_{\mathrm{ex}}=365 \mathrm{~nm}\right)$. The insets show the photographs under a UV lamp.

analysis, the strengthening of the $\mathrm{N}-\mathrm{H} \cdots \mathrm{X}$ hydrogen bond reduces the electron cloud density of the bonding hydrogen, while the donor nitrogen atom gains electron cloud density, leading to the downfield shift of the proton signal of the $\mathrm{N}-\mathrm{H}$ moiety as the counterions of $\left[\mathrm{ppy}_{2} \mathrm{IrNH}\right]^{+} \mathrm{A}^{-}$change from $\mathrm{PF}_{6}^{-}$ to $\mathrm{Cl}^{-}$(see Fig. 2a). According to the theoretical calculation results, the highest occupied molecular orbital (HOMO) is located on the iridium centre and $\mathrm{C}^{\wedge} \mathrm{N}$ ligand (ppy), and the lowest unoccupied molecular orbital (LUMO) is dominated by the $\mathrm{N}^{\wedge} \mathrm{N}$ ligand (see Supplementary Fig. 19). Thus, increasing electron cloud density on the nitrogen atom of the $\mathrm{N}-\mathrm{H}$ moiety will elevate the energy level of LUMO, but with tiny effect on HOMO. As such, $\left[\mathrm{ppy}_{2} \mathrm{IrNH}\right]^{+} \mathrm{A}^{-}$displayed a blue shift of the emission maximum when the counterion changed from $\mathrm{PF}_{6}^{-}$to $\mathrm{Cl}^{-}$. In addition, electrochemical data (see Supplementary Fig. 20 and Supplementary Table 3) showed that the reversible $\operatorname{Ir}(\mathrm{IV} / \mathrm{III})$ oxidation couples of all complexes occurred at $\sim 0.87 \mathrm{~V}$ against ferrocene/ferricenium. The $\mathrm{N}^{\wedge} \mathrm{N}$ ligand-based reduction waves were irreversible, and their potentials became more negative when the counterions of the complexes changed from $\mathrm{PF}_{6}^{-}$through $\mathrm{BF}_{4}^{-}, \mathrm{I}^{-}, \mathrm{Br}^{-}$to $\mathrm{Cl}^{-}$, which is in agreement with the change in emission wavelengths of the complexes. 


\begin{tabular}{|c|c|c|c|c|}
\hline$\underline{A}^{-}$ & $\lambda_{\mathrm{abs}}(\mathrm{nm})(\log \epsilon)$ & $\lambda_{\mathrm{em}}(\mathrm{nm})^{*}$ & $\Phi^{*}$ & $\tau(\mathbf{n s})^{\dagger}$ \\
\hline $\mathrm{PF}_{6}^{-}$ & $\begin{array}{l}320(4.36), 384(3.88) \\
418(3.58), 470(2.89)\end{array}$ & 588 & 0.17 & 189.5 \\
\hline $\mathrm{BF}_{4}^{-}$ & $\begin{array}{l}320(4.42), 382(3.86) \\
420(3.56), 470(2.84)\end{array}$ & 570 & 0.19 & 201.3 \\
\hline $1^{-}$ & $\begin{array}{l}320(4.38), 382(3.94) \\
420(3.59), 470(2.86)\end{array}$ & 556 & 0.08 & $\begin{array}{l}93.7(70.3 \%) \\
207.9(29.7 \%)\end{array}$ \\
\hline $\mathrm{Br}^{-}$ & $\begin{array}{l}320(4.35), 384(3.86) \\
420(3.59), 470(2.89)\end{array}$ & 552 & 0.25 & 261.6 \\
\hline $\mathrm{Cl}^{-}$ & $\begin{array}{l}332(4.34), 420(3.62) \\
470(2.89)\end{array}$ & 532 & 0.14 & $\begin{array}{l}109.9(18.7 \%), \\
276.5(81.3 \%)\end{array}$ \\
\hline
\end{tabular}

To demonstrate the universality of the emission-tuning strategy, complexes $\left[\mathrm{pq}_{2} \mathrm{IrNH}\right]^{+} \mathrm{A}^{-}$have been designed. Their photoluminescence spectra in $\mathrm{CH}_{2} \mathrm{Cl}_{2}$ solution $(10 \mu \mathrm{M})$ are shown in Fig. 3a. Similar to the case of $\left[\mathrm{ppy}_{2} \mathrm{IrNH}\right]^{+} \mathrm{A}^{-}$, a counterion variation induced different emission colours of $\left[\mathrm{pq}_{2} \mathrm{IrNH}\right]^{+} \mathrm{A}^{-}$. However, the emission wavelength tuning range is smaller than that of the ppy analogues. The reasons are as follows: the luminescence of the ppy complexes originates from a triplet metal-to-ligand charge-transfer $\left({ }^{3} \mathrm{MLCT}\right)$ excited state with the LUMO dominated by the $\mathrm{N}^{\wedge} \mathrm{N}$ ligand, while the emissive state of the pq complexes involves predominantly triplet intraligand $\left({ }^{3} \mathrm{IL}\right)$ character with both HOMO and LUMO located on the pq ligand. As a result, the formation of hydrogen bonds between counterions and the $\mathrm{N}^{\wedge} \mathrm{N}$ ligand causes more significant effects on the emission properties of the ppy complexes. This explanation is further supported by the theoretical calculation results (see Supplementary Fig. 19), in which the emissive state of the ppy complexes is more closely related to the electronic property of $\mathrm{N}^{\wedge} \mathrm{N}$ ligand than that of the pq complexes.

To demonstrate the function of the $\mathrm{N}-\mathrm{H}$ moiety in the phosphorescence-tuning strategy, two control complexes $\left[\mathrm{ppy}_{2} \mathrm{IrNEt}\right]^{+} \mathrm{A}^{-}$have been synthesized (see Fig. 1b). The replacement of hydrogen atom in the $\mathrm{N}-\mathrm{H}$ moiety with an ethyl group eliminated the formation of hydrogen bonds, and the emission wavelengths of both complexes were almost the same (see Fig. 3b).

Mechanochromic and vapochromic phosphorescence. $\left[\mathrm{ppy}_{2} \mathrm{IrNH}\right]^{+} \mathrm{PF}_{6}^{-}$was selected to study the potential application of these $\operatorname{Ir}$ (III) complexes as mechanochromic materials. In the solid state, this complex exhibited green colour phosphorescence at $543 \mathrm{~nm}$ and has been named as $\left[\mathrm{ppy}_{2} \mathrm{IrNH}\right]^{+} \mathrm{PF}_{6}^{-}-\mathrm{G}$. Interestingly, grinding this complex on a quartz plate induced a red-shift of the emission maximum to $585 \mathrm{~nm}$ and yielded a yellow-emitting powder $\left[\mathrm{ppy}_{2} \mathrm{IrNH}\right]^{+} \mathrm{PF}_{6}^{-}-\mathrm{Y}$ (see Fig. 4a). Since similar phosphorescence colour change has not been observed when a pressure of $20 \mathrm{MPa}$ is applied to an IR pellet press containing $\left[\mathrm{ppy}_{2} \mathrm{IrNH}\right]^{+} \mathrm{PF}_{6}-\mathrm{G}$ (see Supplementary Fig. 21), the mechanochromic behaviour probably results from the shearing force. Interestingly, exposing this powder to a solvent vapour of $\mathrm{CH}_{2} \mathrm{Cl}_{2}, \mathrm{CHCl}_{3}$ or THF for several seconds will revert the emission colour to green because of vapour-induced recrystallization $^{33}$. A rewritable data recording device has been constructed (see Fig. 4b) based on the reversible mechanochromism and vapochromism of $\left[\mathrm{ppy}_{2} \mathrm{IrNH}\right]^{+} \mathrm{PF}_{6}^{-}$. This complex was grinded and coated on a quartz plate as the 'paper', on which a word 'IAM' was written using a specially made 'pen' with $\mathrm{CH}_{2} \mathrm{Cl}_{2}$ vapour as the 'ink'. In contrast to the yellow-emitting
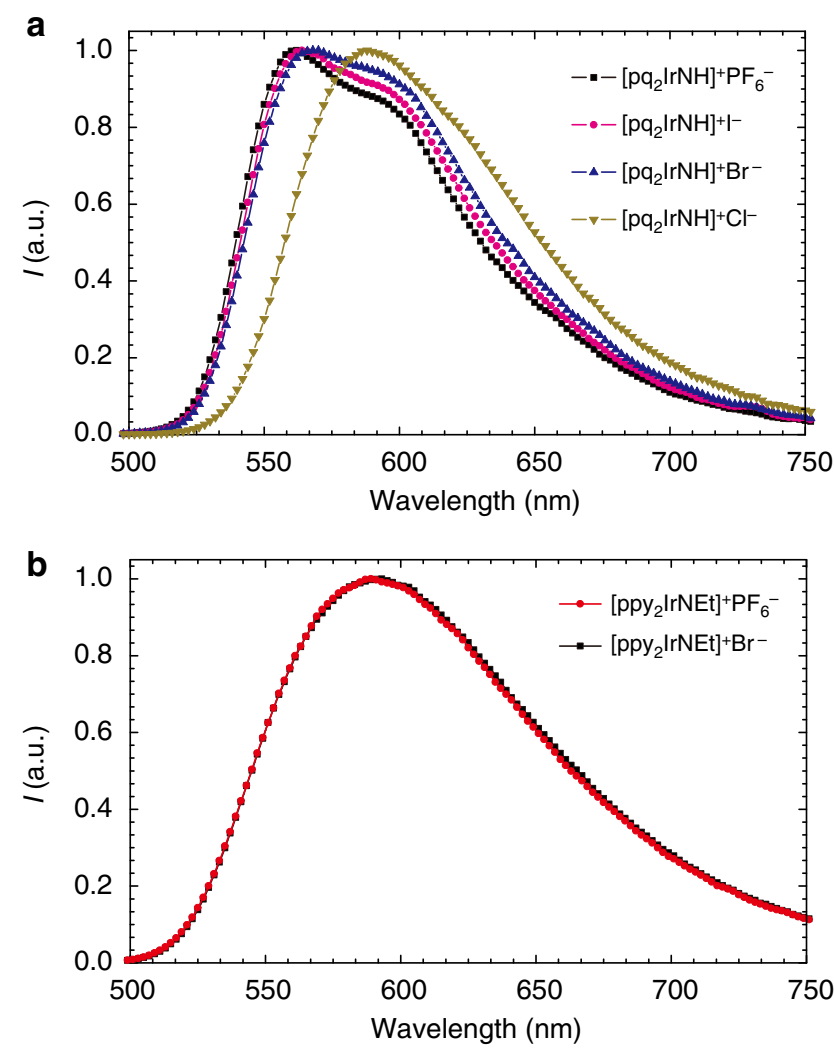

Figure 3 | Optical features of $\left[\mathrm{pq}_{2} \mid \mathrm{IrNH}\right]^{+} \mathbf{A}^{-}$and $\left[\mathrm{ppy}_{2} \mathbf{I r N E t}\right]^{+} \mathbf{A}^{-}$. (a) Normalized photoluminescence spectra of $\left[\mathrm{pq}_{2} \mid \mathrm{rNH}\right]^{+} \mathrm{A}^{-}$in $\mathrm{CH}_{2} \mathrm{Cl}_{2}$ at $296 \mathrm{~K}\left(10 \mu \mathrm{M}, \lambda_{\mathrm{ex}}=365 \mathrm{~nm}\right)$. (b) Normalized photoluminescence spectra of $\left[p p y_{2}\right.$ IrNEt ${ }^{+} \mathrm{A}^{-}$in $\mathrm{CH}_{2} \mathrm{Cl}_{2}$ at $296 \mathrm{~K}\left(10 \mu \mathrm{M}, \lambda_{\mathrm{ex}}=365 \mathrm{~nm}\right)$.

background, the word 'IAM' showed intense green emission. This word can similarly be easily erased by grinding, and the writing and erasing processes can be repeated.

The complete consistency of the characterization data $\left({ }^{1} \mathrm{H}\right.$ NMR and MALDI-TOF MS) of $\left[\mathrm{ppy}_{2} \mathrm{IrNH}^{+}{ }^{+} \mathrm{PF}_{6}^{-}-\mathrm{G}\right.$ and $\left[\right.$ ppy $_{2}$ IrNH] ${ }^{+} \mathrm{PF}_{6}^{-}-\mathrm{Y}$ (see Supplementary Figs 1, 22 and 23) indicated that no change occurred in the molecular structure of the complex during grinding. The difference in the phosphorescence colours has been attributed to the change in the molecular packing mode and intermolecular interactions. To understand the possible origin of this behaviour, the powder X-ray diffraction (PXRD) of the samples was studied. The PXRD patterns and the fluorescence microscopy images of the corresponding samples have been shown in Fig. 4c. PXRD patterns of $\left[\mathrm{ppy}_{2} \mathrm{IrNH}\right]^{+}$ $\mathrm{PF}_{6}^{-}-\mathrm{G}$ showed intense and sharp reflection peaks, which indicated that the aggregate was well ordered. By contrast, $\left[\mathrm{ppy}_{2} \mathrm{IrNH}\right]^{+} \mathrm{PF}_{6}^{-}-\mathrm{Y}$ showed very weak and broad diffraction signals, suggestive of an amorphous or partially amorphous state. After fuming the $\left[\mathrm{ppy}_{2} \mathrm{IrNH}\right]^{+} \mathrm{PF}_{6}^{-}-\mathrm{Y}$ with $\mathrm{CH}_{2} \mathrm{Cl}_{2}$ vapour, the diffraction peaks of the complex (named as $\left[\mathrm{ppy}_{2} \mathrm{IrNH}\right]^{+} \mathrm{PF}_{6}^{-}$ $-\mathrm{Y}-\mathrm{CH}_{2} \mathrm{Cl}_{2}$ ) reappeared (see Fig. 4c), which suggested that the crystalline state was recovered through molecular repacking. Considering the significant function of hydrogen bonds in the phosphorescence colour tuning of $\left[\mathrm{ppy}_{2} \mathrm{IrNH}\right]^{+} \mathrm{A}^{-}$in solution, the green emission of well-ordered $\left[\mathrm{ppy}_{2} \mathrm{IrNH}^{+} \mathrm{PF}_{6}^{-}-\mathrm{G}\right.$ has been tentatively attributed to the hydrogen bond between $\mathrm{PF}_{6}^{-}$ and the $\mathrm{N}^{\wedge} \mathrm{N}$ ligand, which was observed in the single-crystal structure (see Fig. 1c and Supplementary Fig. 13). As a weak molecular interaction, hydrogen bonding is easily broken and rebuilt at specific external stimuli ${ }^{34}$. Hence, the mechanochromism and vapochromism of $\left[\mathrm{ppy}_{2} \mathrm{IrNH}\right]^{+} \mathrm{PF}_{6}^{-}$ 
a

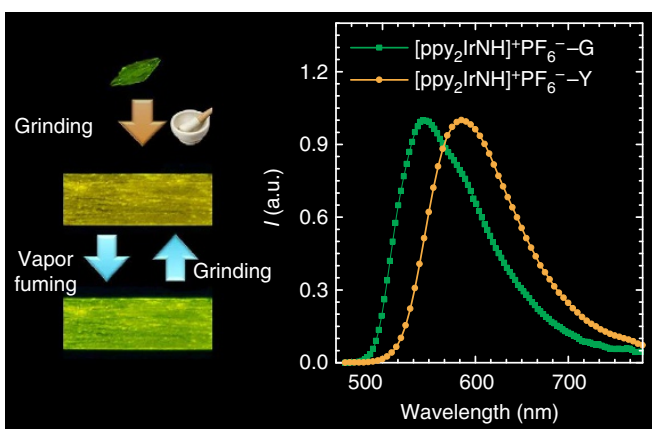

b

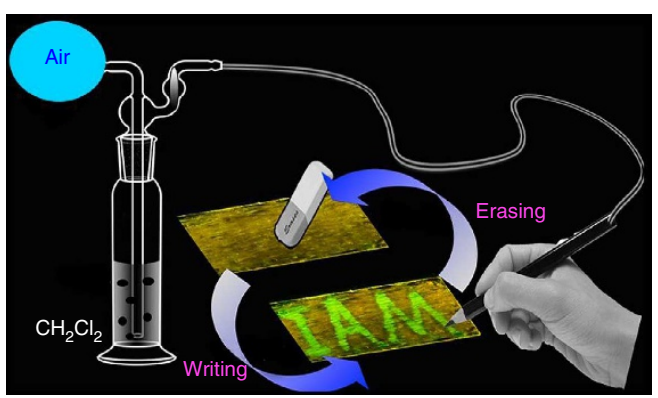

C
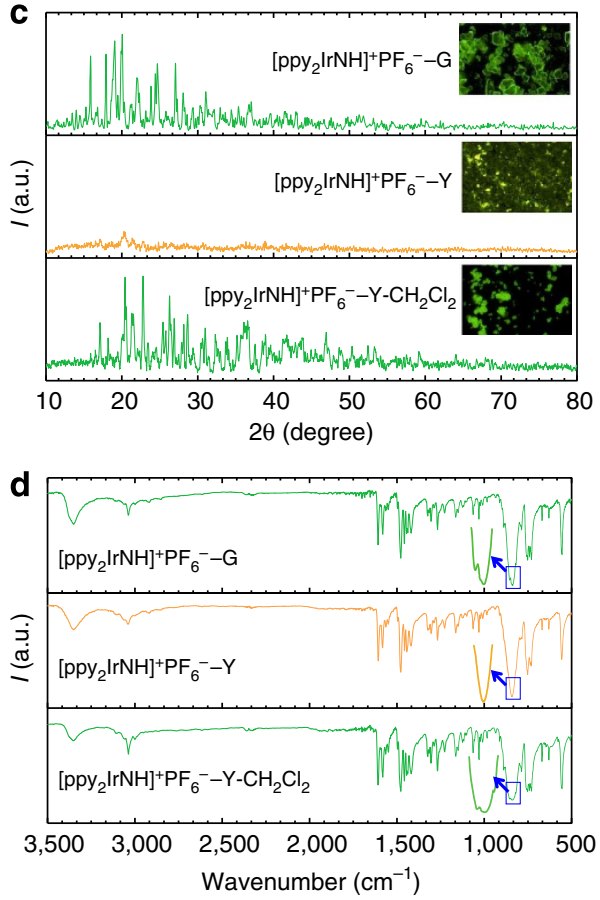

Figure 4 | Mechanochromic and vapochromic experiments. (a) Luminescence photographs and photoluminescence spectra of [ppy $\left.{ }_{2} \mathrm{rNH}\right]^{+}$ $\mathrm{PF}_{6}^{-}$before $\left(\left[\mathrm{ppy}_{2} \mathrm{IrNH}\right]^{+} \mathrm{PF}_{6}^{-}-\mathrm{G}\right)$ and after $\left(\left[\mathrm{ppy}_{2} \mathrm{IrNH}^{+} \mathrm{PF}_{6}^{-}-\mathrm{Y}\right)\right.$ grinding. (b) The constructed rewritable data recording device based on mechanochromic and vapochromic phosphorescence. (c) Power X-ray diffraction patterns of the corresponding samples. (d) FTIR spectra of the corresponding samples.

were probably caused by the breaking and restoring of hydrogen bonds when the complex was subjected to mechanical grinding and exposed to $\mathrm{CH}_{2} \mathrm{Cl}_{2}$ vapour.

To further investigate the effect of external stimuli on hydrogen bonds, FTIR measurements have been performed, which has been widely used to study hydrogen bonds in supramolecular self-assembly ${ }^{35}$. The FTIR spectra of $\left[\mathrm{ppy}_{2} \mathrm{IrNH}^{+} \mathrm{PF}_{6}^{-}-\mathrm{G}\right.$, $\left[\mathrm{ppy}_{2} \mathrm{IrNH}\right]^{+} \mathrm{PF}_{6}^{-}-\mathrm{Y}$ and $\left[\mathrm{ppy}_{2} \mathrm{IrNH}\right]^{+} \mathrm{PF}_{6}^{-}-\mathrm{Y}_{-}-\mathrm{CH}_{2} \mathrm{Cl}_{2}$ have been shown in Fig. 4d. Generally, $\mathrm{PF}_{6}^{-}$displays a monomodal F-P stretching peak around $841 \mathrm{~cm}^{-1}$ in the FTIR spectrum. However, the F-P stretching peak was split into two bands at 854 and $838 \mathrm{~cm}^{-1}$ for $\left[\mathrm{ppy}_{2} \mathrm{IrNH}\right]^{+} \mathrm{PF}_{6}^{-}-\mathrm{G}$ and $\left[\mathrm{ppy}_{2} \mathrm{IrNH}\right]^{+} \mathrm{PF}_{6}^{-}$ $-\mathrm{Y}-\mathrm{CH}_{2} \mathrm{Cl}_{2}$, and this result has been attributed to the inequivalence of the six F-P bonds caused by the $\mathrm{N}-\mathrm{H} \cdots \mathrm{F}$ hydrogen bond. Only one F-P stretching peak at $841 \mathrm{~cm}^{-1}$ was observed for $\left[\mathrm{ppy}_{2} \mathrm{IrNH}\right]^{+} \mathrm{PF}_{6}-\mathrm{Y}$ because the hydrogen bond vanished.

The PXRD data, single-crystal structures and FTIR spectra showed that the observed mechanochromic and vapochromic phosphorescence originated from variations in the molecular packing mode and hydrogen bonds between the counterion and the ligand.

Electrochromic phosphorescence. The response of $\left[\mathrm{ppy}_{2} \mathrm{IrNH}\right]^{+} \mathrm{PF}_{6}^{-}$towards an electrical stimulus has been analysed via electrochromic phosphorescence experiments, because the phosphorescence properties of $\left[\mathrm{ppy}_{2} \mathrm{IrNH}\right]^{+} \mathrm{A}^{-}$are strongly related to the electronic effect of the N-H moiety. As illustrated in Fig. 5a, two tin electrodes were immersed in a $\mathrm{CH}_{3} \mathrm{CN}$ solution of $\left[\mathrm{ppy}_{2} \mathrm{IrNH}\right]^{+} \mathrm{PF}_{6}^{-}(200 \mu \mathrm{M})$ with a distance of $20 \mathrm{~mm}$ between each other. Before applying a voltage, the solution exhibited yellow emission (see Fig. 5a). At voltages higher than $10 \mathrm{~V}$, the emission colour of the solution near the anode remained yellow all throughout. However, green emission was observed near the cathode within several seconds (see Fig. 5a) and gradually extended to the middle of the two electrodes, which revealed a clear boundary (see Fig. 5a and Supplementary Movie 1). This process took several minutes to reach equilibrium depending on the magnitude of the applied voltage. The green emission returned back to yellow upon stirring and reappeared when the stirring was stopped. This phenomenon can be observed repeatedly. Interestingly, when the distribution of the applied electric field was modulated by an additional tin plate placed between the two electrodes, both the separated cells exhibited the similar phenomenon (see Fig. 5a and Supplementary Fig. 24). The interesting electrochromic phosphorescence can be applied to patterning by controlling the distribution of the electric field.

The electrochromic phosphorescence did not originate from redox reactions because no change in emission colour was observed in the cyclic voltammetry experiment of $\left[\mathrm{ppy}_{2} \mathrm{IrNH}\right]^{+}$ $\mathrm{PF}_{6}^{-}$(see Supplementary Movie 2). The Ir(III) complexes near the two electrodes have been characterized to understand the origin of the electrochromic phosphorescence. The ${ }^{1} \mathrm{H}$ NMR and MS results showed that the structures of the complexes remained unchanged at our experimental conditions (see Supplementary Figs 25 and 26). On applying a voltage of $15 \mathrm{~V}$ for $3 \mathrm{~min}$, the concentration of the Ir(III) complex cation increased by $10 \%$ near the cathode and decreased by $9 \%$ near the anode based on the integrals in the ${ }^{1} \mathrm{H}$ NMR spectra (see Fig. $5 \mathrm{c}$ ). The ${ }^{19} \mathrm{~F}$ NMR spectra revealed that the concentration change of $\mathrm{PF}_{6}^{-}$was much more significant; the concentration decreased markedly by $35 \%$ near the cathode and increased by $26 \%$ near the anode (see Fig. 5c,d and Supplementary Fig. 27). As a result, the nonhomogeneous distribution of the ions led to the formation of a strong internal electric field near the cathode ${ }^{36}$. Therefore, the phosphorescence colour change of the solution near the cathode is probably caused by the polarization of the $\mathrm{N}-\mathrm{H}$ bond under the internal electric field. Similar observation was absent in the control experiments, where the ethyl-substituted control complex [ppy $\left.{ }_{2} \mathrm{IrNEt}\right]^{+} \mathrm{PF}_{6}^{-}$was used (see Supplementary Fig. 28), thereby highlighting the significant function of the N-H moiety. 
a

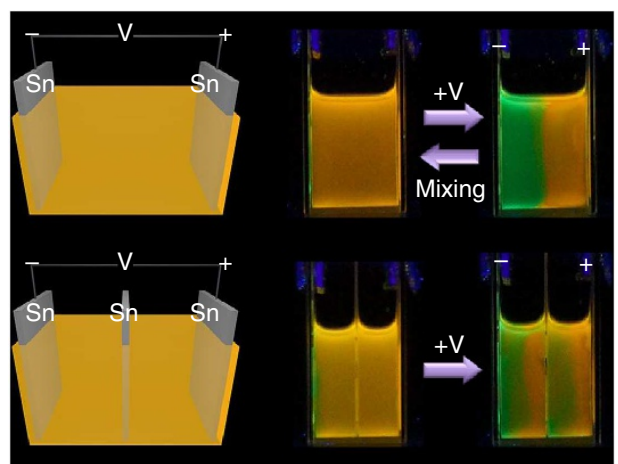

b

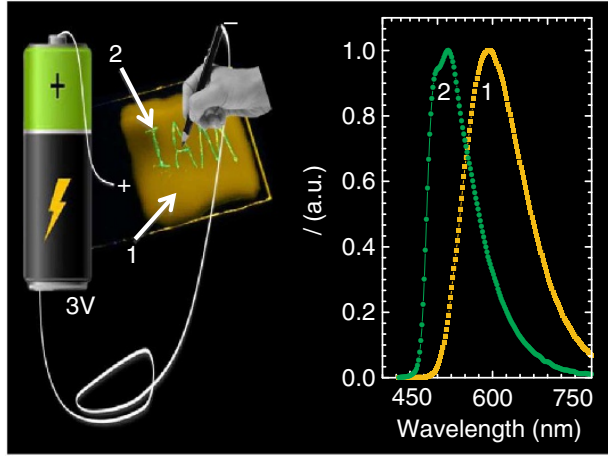

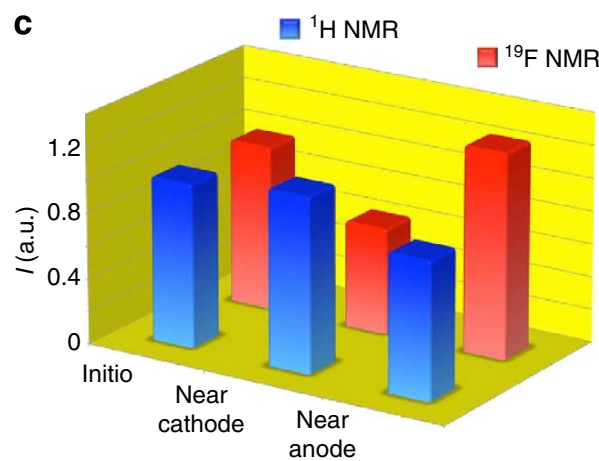

d

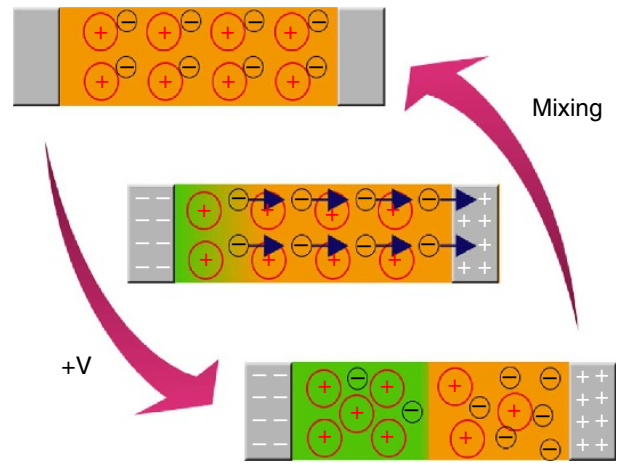

Figure 5 | Electrochromic phosphorescence experiments. (a) The setup used for electrochromic phosphorescence experiments and the photographs of electrochromic phosphorescence of $\left[\mathrm{ppy}_{2} \mathrm{IrNH}\right]^{+} \mathrm{PF}_{6}^{-}(200 \mu \mathrm{M})$ in $\mathrm{CH}_{3} \mathrm{CN}$. (b) Quasi-solid film under a UV lamp. Inset: the emission spectra of $\left[\mathrm{ppy}_{2} \mathrm{IrNH}\right]^{+} \mathrm{PF}_{6}^{-}\left(\lambda_{\mathrm{ex}}=365 \mathrm{~nm}\right)$ before (1) and after (2) applying a voltage in quasi-solid device. (c) Concentration variation of $\left[\mathrm{ppy}{ }_{2} \mathrm{IrNH}\right]^{+}$and $\mathrm{PF}_{6}^{-}$based on the ${ }^{1} \mathrm{H}$ NMR and ${ }^{19} \mathrm{~F}$ NMR spectra. (d) Schematic illustration of the migration and distribution of ions under an electric field.

A quasi-solid film has been fabricated by mixing $\left[\mathrm{ppy}_{2} \mathrm{IrNH}\right]^{+}$ $\mathrm{PF}_{6}^{-}$with ionic liquid $\mathrm{BMIM}^{+} \mathrm{PF}_{6}^{-}$and silica nanoparticles to demonstrate the potential application of the interesting electrochromic phosphorescence for data recording and storage. The ionic liquid was employed because of its high ionic conductivity, thermal stability, negligible vapour pressure and wide electrochemical window ${ }^{37,38}$. The silica nanoparticles functioned as gelators to solidify the ionic liquid-based matrix through the supramolecular interaction (see Supplementary Fig. 29), with negligible influence on the migration of ions owing to the presence of the open channels ${ }^{39}$. Moreover, neither the $\mathrm{BMIM}^{+} \mathrm{PF}_{6}^{-}$nor silica nanoparticles affected the phosphorescence properties of $\left[\mathrm{ppy}_{2} \mathrm{IrNH}\right]^{+} \mathrm{PF}_{6}^{-}$(see Supplementary Figs 30 and 31). In this experiment, the fabricated film was sandwiched between an indium-tin oxide (ITO) anode and a movable Pt needle cathode. The handheld needle electrode functioned as a 'pen' to 'write' the word 'IAM' on the quasi-solid film. The film showed evident emission colour change from yellow to green at the point of 'writing' under a voltage as low as $3 \mathrm{~V}$ (see Fig. 5b). Compared with the case in solution, the quasisolid device required a much lower working voltage due to the rapid formation of the non-homogeneous distribution of ions because the $\mathrm{BMIM}^{+} \mathrm{PF}_{6}^{-}$ionic liquid provided extra $\mathrm{PF}_{6}^{-}$ anions.

Data encryption and decryption. In addition to data recording, information encryption and decryption are important and have received considerable interest among scholars. A new strategy has been designed to achieve this objective. In the encryption process, a fluorescent dye is used to provide short-lifetime interference fluorescence (SLIF) into which the phosphorescence from $\left[\mathrm{ppy}_{2} \mathrm{IrNH}\right]^{+} \mathrm{PF}_{6}^{-}$is completely embedded (see Fig. 6a). For decryption, FLIM is used to highlight long-lived phosphorescence from $\left[\mathrm{ppy}_{2} \mathrm{IrNH}\right]^{+} \mathrm{PF}_{6}^{-}$, or TGLI is employed to filter off shortlived fluorescence from the fluorescent dye. Our idea has been successfully supported and was confirmed by experimental results. The boron-dipyrromethene (BODIPY) dye (see Supplementary Fig. 32) has been selected to provide SLIF because of its intense fluorescence $(\Phi=0.65)$, short lifetime $(\tau=5 \mathrm{~ns})$ and no efficient electronic communication with $\left[\mathrm{ppy}_{2} \mathrm{IrNH}\right]^{+} \mathrm{PF}_{6}^{-}$ (see Supplementary Figs 33 and 34). The steady-state emission spectrum of a mixture of the BODIPY dye $(100 \mu \mathrm{M})$ and [ppy $2 \mathrm{IrNH}]^{+} \mathrm{PF}_{6}^{-}(10 \mu \mathrm{M})$ in $\mathrm{BMIM}^{+} \mathrm{PF}_{6}^{-}$is dominated by the intense emission band of the BODIPY dye, and the emission from $\left[\mathrm{ppy}_{2} \mathrm{IrNH}\right]^{+} \mathrm{PF}_{6}^{-}$is barely observed (see Supplementary Fig. 33d). After a delay of $100 \mathrm{~ns}$, the emission of $\left[\mathrm{ppy}_{2} \mathrm{IrNH}\right]^{+}$ $\mathrm{PF}_{6}^{-}$appeared (see Supplementary Fig. 33d). On the basis of these observations, the BODIPY dye was added to the quasi-solid film containing $\left[\mathrm{ppy}_{2} \mathrm{IrNH}\right]^{+} \mathrm{PF}_{6}^{-}$, forming the 'security paper', which has been placed on a probe station equipped with a needle electrode (see Fig. 6a and Supplementary Fig. 35). After writing a character ' $A$ ' by using the needle electrode 'pen' on the 'security paper', the recorded data were encrypted by the SLIF and could not be observed using a common fluorescent microscopy (see Fig. 6b). To decrypt the data, FLIM was used to differentiate the character ' $\mathrm{A}$ ' from the background by using the emission lifetime instead of the intensity as the reading signal because the lifetime of $\left[\mathrm{ppy}_{2} \mathrm{IrNH}\right]^{+} \mathrm{PF}_{6}^{-}$(189 ns) was much longer than that of the BODIPY dye ( $5 \mathrm{~ns}$ ) (see Fig. 6b). Alternatively, as shown in the time-gated luminescence images (see Fig. 6c), after exerting a delay time of $12 \mathrm{~ns}$, the data ' $\mathrm{A}$ ' became readable. With an increase in the delay time, the signal-to-noise ratio was further enhanced and the recorded 'A' became progressively clearer. The results demonstrate the advantages of phosphorescence signals in data recording and security protection, which can be applied to 
a

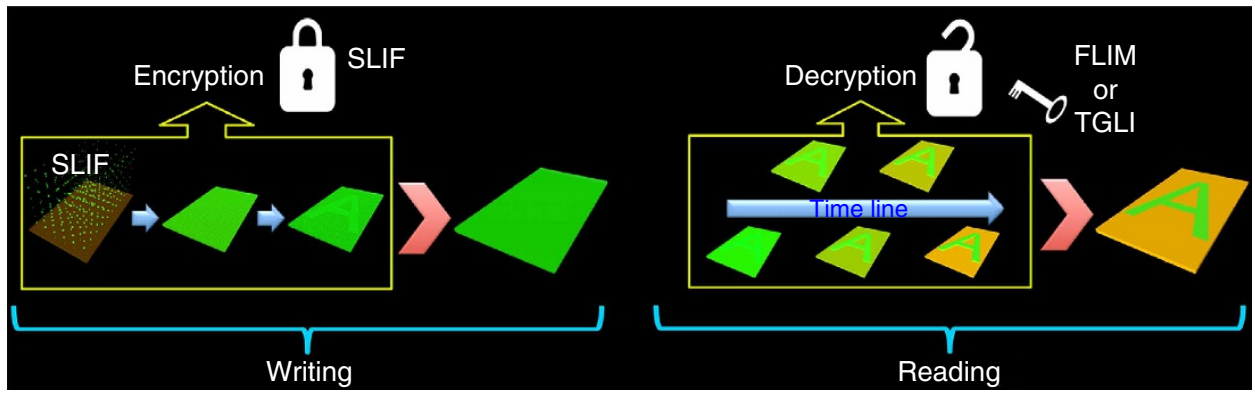

b
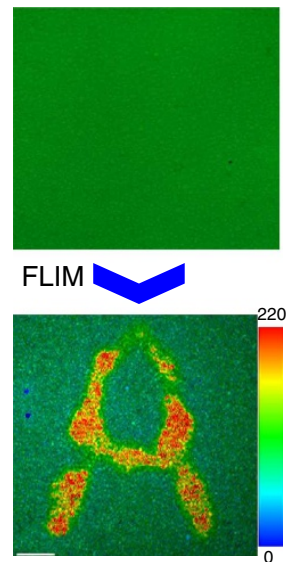

C
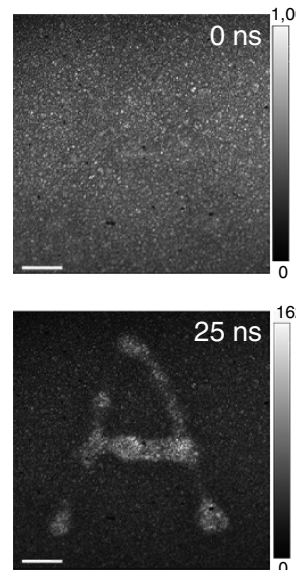
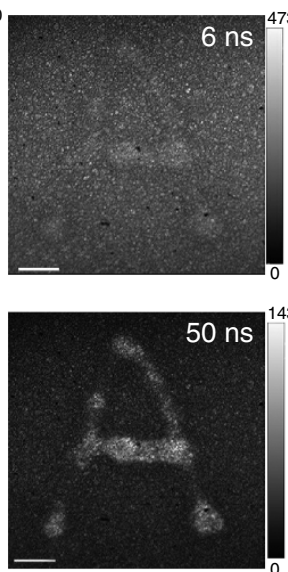
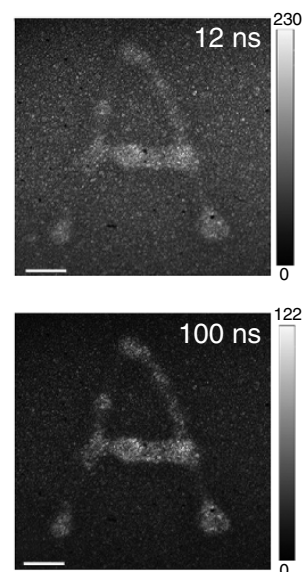

Figure 6 | Data encryption and decryption experiments. (a) Schematic diagram of information encryption and decryption. (b) Photoluminescence and fluorescence lifetime microscopy images (scale bar: average emission lifetime (ns): scale bar (length scale), $500 \mu \mathrm{m}$ ). (c) Time-gated luminescence images with different delay time (scale bar: emission intensity (counts): scale bar (length scale) $500 \mu \mathrm{m}$ ).

the production of secret media, such as identity documents and banknotes.

\section{Discussion}

In this work, we have designed and synthesized a series of ionic $\mathrm{Ir}(\mathrm{III})$ complexes containing a $\mathrm{N}-\mathrm{H}$ moiety in their $\mathrm{N}^{\wedge} \mathrm{N}$ ligand. Their different counterions cause a variation in the emission colours from yellow to green by forming hydrogen bonds with the $\mathrm{N}-\mathrm{H}$ proton. Interestingly, these complexes respond to multiple types of external stimuli including mechanical force, solvent vapour and electric field, resulting in mechanochromic, vapochromic and electrochromic luminescence. On the basis of the mechanochromic and vapochromic phosphorescence of the complexes, a rewritable data recording device has been constructed by using $\mathrm{CH}_{2} \mathrm{Cl}_{2}$ vapour as the 'ink' and mechanical grinding as the 'eraser' for data 'recording' and 'erasing', respectively. A quasi-solid data-recording device has been constructed using the needle electrode as an electric 'pen' based on the unexpected electrochromic phosphorescence of the complexes, and data encryption in the presence of the background fluorescence interference has been demonstrated. Meaningfully, data decryption has been achieved by utilizing FLIM and TGLI techniques, in which the long-lived phosphorescence of $\operatorname{Ir}(\mathrm{III})$ complexes plays an important role. We anticipate that phosphorescent transition-metal complexes will be promising candidates for applications in optical data recording and security protection technology by combining advanced optical imaging techniques.

\section{Methods}

Materials. Unless otherwise stated, all starting materials and reagents were purchased from commercial suppliers and were used without further purification. Silica particles (Aesoil 200, $12 \mathrm{~nm}$ ) were purchased from Degussa Company (Evonik Industries AG, Rellinghauser Straße 1-11, 45128 Essen, Germany). The fluorescent BODIPY dye was synthesized by our group, and its chemical structure was shown in Supplementary Fig. 32. $\mathrm{CH}_{2} \mathrm{Cl}_{2}, \mathrm{CH}_{3} \mathrm{CN}$ and $\mathrm{CDCl}_{3}$ were dried under reflux over $\mathrm{CaH}_{2}$ for several hours at $70-75^{\circ} \mathrm{C}$, distilled at these conditions and used freshly.

Synthesis and characterization of the complexes. A mixture of 2-(2-pyridyl)benzimidazole $(39 \mathrm{mg}, 0.2 \mathrm{mmol})$ and $\left[\operatorname{Ir}(\mathrm{ppy})_{2}(\mu-\mathrm{Cl})\right]_{2}(107 \mathrm{mg}, 0.1 \mathrm{mmol})$ in $\mathrm{CH}_{2} \mathrm{Cl}_{2} / \mathrm{MeOH}(24 \mathrm{ml}, 3: 1, \mathrm{v} / \mathrm{v})$ was heated under reflux in a nitrogen atmosphere with stirring for $4 \mathrm{~h}$. After the clear yellow solution was cooled down to room temperature, $\mathrm{KPF}_{6}(368 \mathrm{mg}, 2 \mathrm{mmol}$ ) was added. The suspension was stirred for $2 \mathrm{~h}$ and filtered to remove insoluble salts. The filtrate was evaporated to dryness under reduced pressure, and the crude product was purified via column chromatography $\left(\mathrm{CH}_{2} \mathrm{Cl}_{2}\right.$ /acetone) over silica gel to give $\left[\mathrm{ppy}_{2} \mathrm{IrNH}\right]^{+} \mathrm{PF}_{6}^{-}$

as yellow crystals. [ppy $\left.{ }_{2} \mathrm{IrNH}\right]^{+} \mathrm{BF}_{4}^{-},\left[\mathrm{ppy}_{2} \mathrm{IrNH}\right]^{+} \mathrm{I}^{-},\left[\mathrm{ppy}_{2} \mathrm{IrNH}\right]^{+} \mathrm{Br}^{-}$ and $\left[\mathrm{ppy}_{2} \mathrm{IrNH}\right]^{+} \mathrm{Cl}^{-}$were obtained through ion exchange reactions of [ppy $\mathrm{IrNH}^{+} \mathrm{PF}_{6}^{-}$with $\mathrm{NaBF}_{4}, \mathrm{KI}, \mathrm{NaBr}$ and $\mathrm{NaCl}$, respectively, in $\mathrm{CH}_{2} \mathrm{Cl}_{2}$ / $\mathrm{MeOH}(3: 1, \mathrm{v} / \mathrm{v})$ with stirring at room temperature for $2 \mathrm{~h}$, followed by column chromatography $\left(\mathrm{CH}_{2} \mathrm{Cl}_{2}\right.$ /acetone) over silica gel and recrystallization from $\mathrm{CH}_{2} \mathrm{Cl}_{2} /$ hexane. [ppy $2 \mathrm{IrNH}{ }^{+} \mathrm{PF}_{6}^{-}$: (Yield, 50\%). ${ }^{1} \mathrm{H}$ NMR $\left(400 \mathrm{MHz}, \mathrm{CDCl}_{3}\right)$ : $\delta=11.81(\mathrm{~s}, 1 \mathrm{H}, \mathrm{NH}), 8.65(\mathrm{~d}, J=8.0 \mathrm{~Hz}, 1 \mathrm{H}, \mathrm{Ar}), 8.10$ (t, $J=7.8 \mathrm{~Hz}, 1 \mathrm{H}, \mathrm{Ar}$ ), 7.96-7.82 (m, 4H, Ar), 7.80-7.62 (m, 5H, Ar), 7.48 (d, J=5.6 Hz, 1H, Ar), 7.42-7.32 (m, 2H, Ar), 7.13-7.03 (m, 2H, Ar), 7.03-6.91 (m, 5H, Ar), 6.45-6.40 (m, $1 \mathrm{H}, \mathrm{Ar}), 6.40-6.35(\mathrm{~m}, 1 \mathrm{H}, \mathrm{Ar}), 6.22(\mathrm{~d}, J=8.4 \mathrm{~Hz}, 1 \mathrm{H}, \mathrm{Ar}) .{ }^{13} \mathrm{C}$ NMR $(100 \mathrm{MHz}$, $\left.\mathrm{CDCl}_{3}\right): \delta=168.23,167.92,152.02,150.75,150.73,149.51,148.33,147.66,146.48$, $144.05,143.92,140.09,139.65,137.85,137.71,134.35,132.37,131.76,130.81$, $130.17,127.70,126.48,125.25,124.78,124.52,124.36,123.30,122.99,122.59$, $122.50,119.37,119.34,117.34,114.56$. MS (ESI) $(m / z)$ : calculated for $\mathrm{C}_{34} \mathrm{H}_{25} \mathrm{IrN}_{5}$ 696.17, found 696.25 [M+ ${ }^{+}$]. [ppy $\left.2 \mathrm{IrNH}\right]^{+} \mathrm{BF}_{4}^{-}$: (Yield, 56\%). ${ }^{1} \mathrm{H}$ NMR $(400 \mathrm{MHz}$, $\left.\mathrm{CDCl}_{3}\right): \delta=12.60(\mathrm{~s}, 1 \mathrm{H}, \mathrm{NH}), 8.78(\mathrm{~d}, J=8.1 \mathrm{~Hz}, 1 \mathrm{H}, \mathrm{Ar}), 8.12-8.04(\mathrm{~m}, 1 \mathrm{H}, \mathrm{Ar})$, 7.94-7.82 (m, 4H, Ar), 7.78-7.63 (m, 5H, Ar), 7.47 (d, J=5.8 Hz, 1H, Ar), 7.41-7.29 (m, 2H, Ar), 7.12-7.02 (m, 2H, Ar), 7.02-6.90 (m, 5H, Ar), 6.46-6.40 (m, 1H, Ar), 6.40-6.34 (m, 1H, Ar), 6.22 (d, J=8.3 Hz, 1H, Ar). ${ }^{13} \mathrm{C}$ NMR $\left(100 \mathrm{MHz}, \mathrm{CDCl}_{3}\right): \delta=168.25,167.94,152.28,150.95,150.58,149.54,148.34$, $147.93,146.63,144.06,143.95,140.13,139.65,137.79,137.64,134.63,132.38$, $131.78,130.78,130.14,127.55,126.24,125.07,124.76,124.72,124.50,123.25$, $122.93,122.54,122.44,119.33,119.31,117.23,114.71$. MS (ESI) $(m / z)$ : calculated for $\mathrm{C}_{34} \mathrm{H}_{25} \mathrm{IrN}_{5} 696.17$, found $696.25\left[\mathrm{M}^{+}\right.$]. [ppy $2 \mathrm{IrNH}{ }^{+} \mathrm{I}^{-}$: (Yield, $58 \%$ ). ${ }^{1} \mathrm{H}$ $\operatorname{NMR}\left(400 \mathrm{MHz} \mathrm{CDCl}_{3}\right): \delta=16.00-12.40$ (broad, $\left.1 \mathrm{H}, \mathrm{NH}\right), 9.55(\mathrm{~d}, J=8.0 \mathrm{~Hz}, 1 \mathrm{H}$, Ar), 8.10-8.01 (m, 2H, Ar), 7.94-7.82 (m, 3H, Ar), 7.77-7.62 (m, 5H, Ar), 7.50-7.45 (m, 1H, Ar), 7.38-7.28 (m, 2H, Ar), 7.12-7.01 (m, 2H, Ar), 7.01-6.89 
(m, 5H, Ar), 6.46-6.41 (m, 1H, Ar), 6.40-6.35 (m, 1H, Ar), $6.20(\mathrm{~d}, J=8.3 \mathrm{~Hz}, 1 \mathrm{H}$, Ar). ${ }^{13} \mathrm{C}$ NMR $\left(100 \mathrm{MHz}, \mathrm{CDCl}_{3}\right): \delta=168.28,167.98,152.92,151.37,150.36$, $149.56,148.54,148.35,146.90,144.07,144.00,140.19,139.29,137.71,137.53$, $135.15,132.39,131.82,130.73,130.08,127.23,126.18,125.63,124.72,124.69$, 124.46, 123.18, 122.83, 122.44, 122.35, 119.28, 119.27, 117.10, 114.74. MS (ESI) $(\mathrm{m} / z)$ : calculated for $\mathrm{C}_{34} \mathrm{H}_{25} \mathrm{IrN}_{5} 696.17$, found $696.33\left[\mathrm{M}^{+}\right]$. $\left[\mathrm{ppy}_{2} \mathrm{IrNH}\right]^{+} \mathrm{Br}^{-}$: (Yield, 57\%). ${ }^{1} \mathrm{H}$ NMR (400 MHz, $\mathrm{CDCl}_{3}$ ): $\delta=16.30-14.50$ (broad, $1 \mathrm{H}, \mathrm{NH}$ ), 9.66 $(\mathrm{d}, J=8.0 \mathrm{~Hz}, 1 \mathrm{H}, \mathrm{Ar}), 8.07(\mathrm{t}, J=8.4 \mathrm{~Hz}, 1 \mathrm{H}, \mathrm{Ar}), 7.97(\mathrm{~d}, J=8.3 \mathrm{~Hz}, 1 \mathrm{H}, \mathrm{Ar})$, 7.92-7.82 (m, 3H, Ar), 7.77-7.62 (m, 5H, Ar), 7.47 (d, $J=5.6 \mathrm{~Hz}, 1 \mathrm{H}, \mathrm{Ar})$, 7.36-7.27 (m, 2H, Ar), 7.12-7.01 (m, 2H, Ar), 6.99-6.89 (m, 5H, Ar), 6.46-6.41 (m, 1H, Ar), 6.41-6.35 (m, 1H, Ar), 6.19 (d, $J=8.3 \mathrm{~Hz}, 1 \mathrm{H}, \mathrm{Ar}) .{ }^{13} \mathrm{C}$ NMR $\left(100 \mathrm{MHz}, \mathrm{CDCl}_{3}\right): \delta=168.28,167.98,152.76,151.41,150.25,149.54,148.54$, $148.34,146.96,144.08,144.01,140.05,139.43,137.69,137.52,134.92,132.40$, $131.82,130.72,130.07,127.20,126.39,125.61,124.71,124.66,124.45,123.15$, $122.79,122.42,122.33,119.28,119.26,117.08,114.73$. MS (ESI) $(m / z)$ : calculated for $\mathrm{C}_{34} \mathrm{H}_{25} \mathrm{IrN}_{5} 696.17$, found $696.33\left[\mathrm{M}^{+}\right]$. [ $\mathrm{ppy}_{2} \mathrm{IrNH}{ }^{+} \mathrm{Cl}^{-}$: (Yield, $\left.53 \%\right) .{ }^{1} \mathrm{H}$ $\operatorname{NMR}\left(400 \mathrm{MHz}, \mathrm{CDCl}_{3}\right): \delta=17.34-15.23($ broad, $1 \mathrm{H}, \mathrm{NH}), 9.69(\mathrm{~d}, J=8.0 \mathrm{~Hz}, 1 \mathrm{H}$, Ar), 8.09-8.02 (m, 1H, Ar), 7.97-7.78 (m, 4H, Ar), 7.77-7.60 (m, 5H, Ar), 7.527.44 (m, 1H, Ar), 7.34-7.26 (m, 2H, Ar), 7.11-7.00 (m, 2H, Ar), 6.99-6.86 (m, 5H, Ar), 6.45-6.41 (m, 1H, Ar), 6.41-6.35 (m, $1 \mathrm{H}, \mathrm{Ar}), 6.19(\mathrm{~d}, J=8.4 \mathrm{~Hz}, 1 \mathrm{H}$, Ar). ${ }^{13} \mathrm{C}$ NMR $\left(100 \mathrm{MHz}, \mathrm{CDCl}_{3}\right): \delta=168.30,168.00,153.01,151.63,150.14$, $149.55,148.83,148.35,147.13,144.09,144.04,140.18,139.43,137.64,137.46$, $135.34,132.41,131.84,130.69,130.03,127.05,126.34,125.37,124.69,124.48$, $124.43,123.10,122.74,122.37,122.27,119.25,119.23,117.01,114.88$. MS (ESI) $(\mathrm{m} / \mathrm{z})$ : calculated for $\mathrm{C}_{34} \mathrm{H}_{25} \mathrm{IrN}_{5} 696.17$, found $696.33\left[\mathrm{M}^{+}\right]$.

Theoretical calculations. The calculation was performed using the Gaussian 09 suite of programs ${ }^{40}$. The optimizations of the complex structures were performed by using B3LYP DFT. The LANL2DZ basis set was used to treat the iridium atom, whereas the $6-31 \mathrm{G}^{*}$ basis set was used to treat all other atoms. The contours of the HOMO and LUMO were plotted.

Crystal and powder sample preparation. Typical preparation procedures are as follows. The single crystal of the complexes was grown from their dichloromethane solution mixed with hexane. Hexane $(20 \mathrm{ml})$ was poured into the solution of [ppy $2 \mathrm{IrNH}]^{+} \mathrm{PF}_{6}^{-}(30 \mathrm{mg})$ in $\mathrm{CH}_{2} \mathrm{Cl}_{2}(20 \mathrm{ml})$. This mixture was allowed to settle for a few minutes. The precipitate was collected as the green emission powder $\left[\mathrm{ppy}_{2} \mathrm{IrNH}\right]^{+} \mathrm{PF}_{6}^{-}-\mathrm{G}$.

Measurements. NMR spectra were recorded on a Bruker Ultra Shield Plus $400 \mathrm{MHz}$ NMR instrument $\left({ }^{1} \mathrm{H}: 400 \mathrm{MHz},{ }^{19} \mathrm{~F}: 377 \mathrm{MHz}\right)$. Mass spectra were obtained on a LCQ Fleet ESI mass spectrometer or a Bruker autoflex MALDI-TOF/TOF mass spectrometer. Photoluminescence spectra were recorded on an Edinburgh FL920 spectrofluorometer system. The absolute quantum yields of the complexes were determined through an absolute method by employing an integrating sphere. Time-resolved fluorescence lifetime measurements were carried out by using time-correlated single-photon counting lifetime spectroscopy system Edinburgh FL920 with a semiconductor laser as the excitation source $\left(\lambda_{\mathrm{ex}}=379\right.$ $\mathrm{nm})$. The quality of the fit has been judged by goodness-of-fit parameters such as $\chi^{2}$-test $(<1.2)$. FTIR spectra were recorded on a Shimadzu IRPrestige-21 spectrometer. Single-crystal X-ray analysis was performed on a Bruker Smart Apex CCD diffractometer with graphite monochromated Mo-K $\alpha$ radiation $(\lambda=0.71073)$ using the $\omega-2 \theta$ scan mode. The structures were solved by direction methods and refined by full-matrix least-squares against $F^{2}$ for all data using SHELX-97 (SMART, SAINT, SADABS and SHELXTL, Bruker AXS Inc., Madison, 2000). All calculations and molecular graphics were carried out on a computer using the SHELX-2000 program package and Mercury 3.0. The powder diffraction data were recorded at room temperature on a Rigaku Dmax 2000 with $\mathrm{Cu} K_{\alpha}$ radiation and a $\mathrm{D} / \mathrm{teX}$ Ultra detector covering $10-80^{\circ}(2 \theta)$. The diffraction data were collected at $20^{\circ} \mathrm{C}$. Unless otherwise stated, all the mechanochromic, vapochromic and electrochromic phosphorescence experiments were carried out at room temperature.

FLIM and TGLI. The FLIM imaging setup was integrated with an Olympus IX81 laser scanning confocal microscopy. The fluorescence signal was detected using the confocal microscopy, and correlative calculation of the data was performed by professional software, which was provided by PicoQuant company. A 405-nm picosecond-pulsed diode laser $(<1 \mu \mathrm{W})$ with $2.5 \mathrm{MHz}$ repetition rate was used for excitation. The time-resolved emission signals were obtained via a TCSPC technique. Typically, the device with the written 'A' was put on the platform, and a $2 \mathrm{~mm} \times 2 \mathrm{~mm}$ sample area consisting of $200 \times$ pixels was scanned with an acquisition rate of $2 \mathrm{~ms}$ per pixel. TGLI were obtained by collecting fluorescence signals with different delay times based on the obtained FLIM images.

\section{References}

1. Irie, M., Fukaminato, T., Sasaki, T., Tamai, N. \& Kawai, T. Organic chemistry: A digital fluorescent molecular photoswitch. Nature 420, 759-760 (2002).
2. Kishimura, A., Yamashita, T., Yamaguchi, K. \& Aida, T. Rewritable phosphorescent paper by the control of competing kinetic and thermodynamic self-assembling events. Nat. Mater. 4, 546-549 (2005).

3. Mutai, T., Satou, H. \& Araki, K. Reproducible on-off switching of solid-state luminescence by controlling molecular packing through heat-mode interconversion. Nat. Mater. 4, 685-687 (2005).

4. Sagara, Y. \& Kato, T. Mechanically induced luminescence changes in molecular assemblies. Nat. Chem. 1, 605-610 (2009).

5. Wu, Y. et al. Quantitative photoswitching in bis(dithiazole)ethene enables modulation of light for encoding optical signals. Angew. Chem. Int. Ed. 53, 2090-2094 (2014).

6. Sagara, Y., Mutai, T., Yoshikawa, I. \& Araki, K. Material design for piezochromic luminescence: Hydrogen-bond-directed assemblies of a pyrene derivative. J. Am. Chem. Soc. 129, 1520-1521 (2007).

7. Kunzelman, J., Kinami, M., Crenshaw, B. R., Protasiewicz, J. D. \& Weder, C. Oligo(p-phenylene vinylene)s as a "new" class of piezochromic fluorophores. Adv. Mater. 20, 119-120 (2008).

8. Sagara, Y. \& Kato, T. Stimuli-responsive luminescent liquid crystals: change of photoluminescent colors triggered by a shear-induced phase transition. Angew. Chem. Int. Ed. 47, 5175-5178 (2008).

9. Chung, J. W. et al. Shear- and UV-induced fluorescence switching in stilbenic pi-dimer crystals powered by reversible $2+2$ cycloaddition. J. Am. Chem. Soc. 131, 8163-8172 (2009).

10. Luo, X. et al. Reversible switching of the emission of diphenyldibenzofulvenes by thermal and mechanical stimuli. Adv. Mater. 23, 3261-3262 (2011).

11. Yoon, S. J. et al. Multistimuli two-color luminescence switching via different slip-stacking of highly fluorescent molecular sheets. J. Am. Chem. Soc. 132, 13675-13683 (2010).

12. Ni, J., Zhang, X., Wu, Y. H., Zhang, L. Y. \& Chen, Z. N. Vapor- and mechanical-grinding-triggered color and luminescence switches for bis(sigma-fluorophenylacetylide) platinum(II) complexes. Chem. Eur. J. 17, 1171-1183 (2011).

13. Powell, A. B., Bielawski, C. W. \& Cowley, A. H. Design, synthesis, and study of main chain poly ( $N$-heterocyclic carbene) complexes: applications in electrochromic devices. J. Am. Chem. Soc. 132, 10184-10194 (2010).

14. Beaujuge, P. M. \& Reynolds, J. R. Color control in pi-conjugated organic polymers for use in electrochromic devices. Chem. Rev. 110, 268-320 (2010).

15. Amb, C. M., Dyer, A. L. \& Reynolds, J. R. Navigating the color palette of solution-processable electrochromic polymers. Chem. Mater. 23, 397-415 (2011).

16. Inagi, S., Nagai, H., Tomita, I. \& Fuchigami, T. Parallel polymer reactions of a polyfluorene derivative by electrochemical oxidation and reduction. Angew. Chem. Int. Ed. 52, 6616-6619 (2013).

17. Baldo, M. A. et al. Highly efficient phosphorescent emission from organic electroluminescent devices. Nature 395, 151-154 (1998).

18. Lamansky, S. et al. Highly phosphorescent bis-cyclometalated iridium complexes: synthesis, photophysical characterization, and use in organic light emitting diodes. J. Am. Chem. Soc. 123, 4304-4312 (2001).

19. Mydlak, M. et al. Positively charged iridium(III) triazole derivatives as blue emitters for light-emitting electrochemical cells. Adv. Funct. Mater. 20, 1812-1820 (2010).

20. Sasabe, H. et al. High-efficiency blue and white organic light-emitting devices incorporating a blue iridium carbene complex. Adv. Mater. 22, 5003-5004 (2010).

21. Strassert, C. A. et al. Switching on luminescence by the self-assembly of a platinum(II) complex into gelating nanofibers and electroluminescent films. Angew. Chem. Int. Ed. 50, 946-950 (2011).

22. Balch, A. L. Dynamic crystals: Visually detected mechanochemical changes in the luminescence of gold and other transition-metal complexes. Angew. Chem Int. Ed. 48, 2641-2644 (2009).

23. Mauro, M. et al. Complex iridium(III) salts: luminescent porous crystalline materials. Angew. Chem. Int. Ed. 49, 1222-1226 (2010).

24. Botchway, S. W. et al. Time-resolved and two-photon emission imaging microscopy of live cells with inert platinum complexes. Proc. Natl Acad. Sci. 105, 16071-16076 (2008).

25. You, Y. et al. Phosphorescent sensor for biological mobile zinc. J. Am. Chem. Soc. 133, 18328-18342 (2011).

26. Marcus, Y. Thermodynamics of solvation of ions.5. gibbs free-energy of hydration at 298.15-K. J. Chem. Soc. Faraday Trans. 87, 2995-2999 (1991).

27. Lungwitz, R. \& Spange, S. A hydrogen bond accepting (HBA) scale for anions, including room temperature ionic liquids. New J. Chem. 32, 392-394 (2008).

28. Steiner, T. The hydrogen bond in the solid state. Angew. Chem. Int. Ed. 41, 48-76 (2002).

29. Alabugin, I. V., Manoharan, M., Peabody, S. \& Weinhold, F. Electronic basis of improper hydrogen bonding: A subtle balance of hyperconjugation and rehybridization. J. Am. Chem. Soc. 125, 5973-5987 (2003).

30. Meot-Ner, M. The ionic hydrogen bond. Chem. Rev. 105, 213-284 (2005). 
31. Jeffrey, G. A. An introduction to hydrogen bonding Vol. 30 (Oxford University Press, 1997).

32. McClure, D. S. Triplet-singlet transitions in organic molecules. Lifetime measurements of the triplet state. J. Chem. Phys. 17, 905-913 (1949).

33. Wang, J. et al. Click synthesis, aggregation-induced emission, E/Z isomerization, self-organization, and multiple chromisms of pure stereoisomers of a tetraphenylethene-cored luminogen. J. Am. Chem. Soc. 134, 9956-9966 (2012).

34. Cordier, P., Tournilhac, F., Soulie-Ziakovic, C. \& Leibler, L. Self-healing and thermoreversible rubber from supramolecular assembly. Nature 451, 977-980 (2008).

35. García, F. \& Sánchez, L. Structural rules for the chiral supramolecular organization of OPE-based discotics: induction of helicity and amplification of chirality. J. Am. Chem. Soc. 134, 734-742 (2011).

36. Slinker, J. D. et al. Direct measurement of the electric-field distribution in a light-emitting electrochemical cell. Nat. Mater. 6, 894-899 (2007).

37. Hagfeldt, A., Boschloo, G., Sun, L., Kloo, L. \& Pettersson, H. Dye-sensitized solar cells. Chem. Rev. 110, 6595-6663 (2010)

38. Costa, R. D., Pertegas, A., Orti, E. \& Bolink, H. J. Improving the turn-on time of light-emitting electrochemical cells without sacrificing their stability. Chem. Mater. 22, 1288-1290 (2010).

39. Wang, P., Zakeeruddin, S. M., Comte, P., Exnar, I. \& Grätzel, M. Gelation of ionic liquid-based electrolytes with silica nanoparticles for quasi-solid-state dye-sensitized solar cells. J. Am. Chem. Soc. 125, 1166-1167 (2003).

40. Frisch, M. J. et al. Gaussian 09, Revision C.01 (Gaussian, Inc., Wallingford CT, 2009).

\section{Acknowledgements}

We acknowledge the funding support from National Basic Research Program of China (2009CB930601 and 2012CB933301), National Natural Science Foundation of China $(61274018,61136003,21174064$ and 21171098), the Ministry of Education of China (IRT1148), Program for New Century Excellent Talents in University (NCET-12-0740), Natural Science Foundation of Jiangsu Province of China (BK20130038), Priority Academic Program Development of Jiangsu Higher Education Institutions (YX03001).

\section{Author contributions}

H.S., Q.Z. and W.H. conceived the idea for this work and designed the experiments. H.S and S.L. performed the experiments. W.L. and H.Y. contributed to the implementation of the experiments and the measurements. W.L. assisted with sample characterization and the equipment setup. H.S., S.L., K.Y.Z., Q.Z. and W.H. analysed the data and wrote the manuscript. X.H., F.H. and G.J. revised the manuscript and provided some suggestions. All authors discussed the results and commented on the manuscript at all stages.

\section{Additional information}

Accession codes: The X-ray crystallographic coordinates for $\left[\mathrm{ppy}_{2} \mathrm{IrNH}\right]+\mathrm{PF}_{6}^{-}(296 \mathrm{~K})$ $\left[\mathrm{ppy}_{2} \mathrm{IrNH}\right]^{+} \mathrm{PF}_{6}^{-}(120 \mathrm{~K}),\left[\mathrm{ppy}_{2} \mathrm{IrNH}\right]^{+} \mathrm{BF}_{4}^{-}(296 \mathrm{~K})$ and $\left[\mathrm{ppy}_{2} \mathrm{IrNH}\right]^{+} \mathrm{Br}^{-}(296 \mathrm{~K})$ have been deposited at the Cambridge Crystallographic Data Centre (CCDC), under deposition number CCDC 958057, 981977, 958058 and 958059. These data can be obtained free of charge from The Cambridge Crystallographic Data Centre via www.ccdc.cam.ac.uk/data_request/cif.

Supplementary Information accompanies this paper at http://www.nature.com/ naturecommunications

Competing financial interests: The authors declare no competing financial interests.

Reprints and permission information is available online at http://npg.nature.com/ reprintsandpermissions/

How to cite this article: Sun, H. et al. Smart responsive phosphorescent materials for data recording and security protection. Nat. Commun. 5:3601 doi: 10.1038/ncomms4601 (2014). 